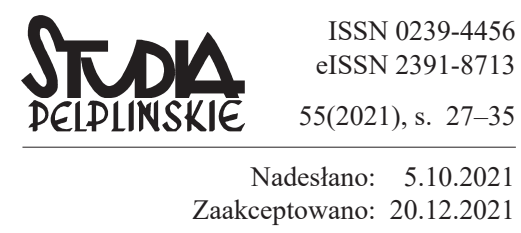

DANIEL BIAEECKI

Uniwersytet Kardynała Stefana Wyszyńskiego w Warszawie

daniel.bialecki@student.uksw.edu.pl

ORCID: orcid.org/0000-0003-3694-7549

\title{
NORMY UPRAWIANIA NAUKI W BADANIACH HISTORYCZNYCH
}

DOI: http://dx.doi.org/10.12775/SPLP.2021.002

\begin{abstract}
Streszczenie
Postulowane normy etycznej analizy badawczej dotyczą w znacznej mierze poziomu percepcji w sposobie budowania narracji historycznej. Z problemem tym przychodzi zetknąć się również na polu badań historycznych prowadzonych w obrębie aspektu cywilizacyjnego kontekstu wojen, który przeobraża rzeczywistość, odciskając na niej swoje piętno, zarówno erodujące ład systemu geopolitycznego, jak i krystalizujące nadejście nowego. Odniesienie zagadnień etycznych teorii wojny, jako głównego czynnika cywilizacyjnego, do wytycznych historiografii i uwarunkowań na nią składających się pozwala nakreślić tło dla analizy pojęcia etyki w badaniach naukowych. Autor przedstawia zbiór istotnych z punktu widzenia rzemiosła historycznego norm uprawiania nauki w praktyce wyzwań, jakich nastręczają mu uwarunkowania metodologiczne, dydaktyczne i terminologiczne w zestawieniu z badanym zjawiskiem dziejowym. Pozwoliło to na dogłębne przyjrzenie się wyzwaniom, przed jakimi staje historyk w toku pracy nad hermeneutyką źródła.
\end{abstract}

Słowa kluczowe: etyczna teoria wojny, etyka badań naukowych, narracja historyczna, normy etyczne, heureza źródtowa, konflikt interesów, faktografia dziejowa, popularyzacja historii 


\title{
NORMS OF DOING HISTORICAL RESEARCH
}

\begin{abstract}
The proposed norms of ethical research analysis largely concern the level of perception in the way historical narration is constructed. This problem may also arise in the field of historical research conducted within in the civilisational context of wars which transforms reality and leave their mark by eroding the previous order of geopolitical system and creating a new one. The inclusion of ethical issues of the theory of war as the main factor of civilisation to the guidelines of broadly understood historiography allows us to outline the background for the analysis of the concept of ethics in the scientific research. The author of this paper presents a set of historically relevant norms related to historical research taking into account practical challenges posed by methodological, didactic and terminological conditions in relation to historical phenomena. This allows for an in-depth look at the challenges a historian faces when working on the hermeneutics of a source.
\end{abstract}

Keywords: ethical theory of war, research ethics, historical narrative, ethical norms, source heuristics, conflict of interest, historiography, popularisation of history

Mówiąc o uniwersalizmie w teorii badań historii, trudno nie nawiązać do założeń etyki oraz pragmatyki, mającej swoją egzemplifikację w kulturotwórczym aspekcie bytu ludzkiego. Moralna strona jest nieodłącznym czynnikiem warunkującym występowanie określonych idei i wartości, które to imponderabilia, jak ofiarność stanowią desygnat poświęcenia $\mathrm{w}$ dążeniu do materializacji swoich celów, urzeczywistniających się w obowiązkach na poziomie wspólnoty. Ujęcie „etycznej teorii wojny”, jakie sformułował w swoich rozważaniach prof. Lech Wyszczelski, bardzo dokładnie odwzorowuje kult heroizmu w odwołaniu do genezy wojny formułowanej na bazie jej platońskiej percepcji, jako procesu społecznego wskutek powszechności konfliktów ${ }^{1}$.

Znajduje to swe odwzorowanie również w modelu etyki wojskowej najwybitniejszego logika XX wieku, którego tytuł bez wątpienia należy się o. Józefowi Marii Bocheńskiemu OP. To w jego epokowych pracach, fundowanych na bazie własnych doświadczeń z udziału w wojnie polsko-bolszewickiej, wykrystalizowała się idea aksjologii wojny w pojmowaniu ludzkiej woli, sprzężonej z hartem ducha przez wyostrzenie cech wartości moralnych. Zatem do pryncypiów jej zaklasyfi-

L. Wyszczelski, Teorie wojenne i ich twórcy na przestrzeni dziejów. Myśl wojskowa od powstania do końca lat osiemdziesiatych XX wieku, Warszawa 2009, s. 176-183. 
kowano dwa główne aksjomaty: bohaterstwo zasadzające się w karności i miłości względem ojczyzny oraz honor będący wyrazem rękojmi dla danego słowa. W świetle założeń teorii etyki, na kanwie autorytetu wybitnych jej teoretyków, bezwzględnie wojna jawi się złem jedynie wówczas, gdyby poddawać analizie sam okres działań wojennych. Poza nim, nauczeni praktyką dziejową uznajemy, że nieodłącznymi jej konsekwencjami jest aktywizacja przemian w obszarze cywilizacji, a tym samym rozwój nauki i kultury. Za przykład niech posłużą nam choćby kazimierzowskie śluby jasnogórskie z 1656 roku, trwale wpisane w kult maryjny narodu ${ }^{2}$.

Spośród wielu metod narracji dziejowej zbudowanej na propagowaniu postaw zaufania wobec społecznej misji historii, jako dziedziny nauki oraz historyków, jako jej wyrazicieli bądź głównych popularyzatorów w przestrzeni publicznej, wyrażono cele w toku badań naukowych rzetelnie odwzorowujących normy, jakie winny obowiązywać na poziomie standardów naszych projektów, czy prac badawczych. Przyjęcie określonych kryteriów dowodzenia i wnioskowania dla formułowanych opinii, czy zajmowania stanowiska w danej sprawie, winno odbywać się przy pełnym poszanowaniu wiarygodności tudzież weryfikowalności tychże metod narracyjnych do przekazywania wiedzy o wiekach przeszłych i ich kontekstu w ukształtowaniu realiów obecnej rzeczywistości, która bez względu na kanony wpisuje się w założenia antropologii naukowej ${ }^{3}$. Istotę zagadnienia wobec niezależności prowadzonych badań oddaje stałe w przypadku historyków dążenie do obiektywizmu w badaniach. Przejawia się to w poszukiwaniach prawdy, przy założeniu gwarancji dla obiektywizacji nauki na przestrzeni do niczym nieograniczonego korzystania z wolności w aspekcie nominalizacji praw. Nadrzędnym celem formułowania zasad w tym względzie będzie, uniwersalne w tradycji pokoleniowej, założenie ochrony dziedzictwa i kultury narodowej, a także jego jak najszersze spopularyzowanie i przenikanie do zbiorowej pamięci na poziomie naukowej dedukcji o dawnych dziejach, czerpiącej swoje źródło z wiedzy weryfikowalnej, w tym też odżegnywanie się od argumentacji pozanaukowej w dyskusji, bądź praktyk wynoszących na piedestał teorie światopoglądowe pozbawione aparatu naukowego ${ }^{4}$.

Kluczowy przedmiot eksploracji badawczej stanowi w samej dziedzinie, jak również w badaniach okołohistorycznych źródło - namacalny wytwór przeszłości o wysokiej wartości cywilizacyjnej oraz przekazujący wiedzę o epoce, z której

2 J. M. Bocheński, De Virtute Militari. Zarys etyki wojskowej, Kraków 1993, s. 18-21; D. Pełka, Etyka wojskowa i jej współczesne egzemplifikacje w zawodach ratowniczych, „Filo-Sofija”, t. 2, 2013, nr 21, s. 285-292.

3 N. Aleksiun i in., Etyka w badaniach przeszłości. Ankieta, „Rocznik Antropologii Historii”, t. 2, 2012, nr 1, s. 301-331.

4 I. Terela, Wybrane problemy etyczne w historii mówionej. Refleksje historyka, „Przegląd Socjologii Jakościowej”, t. 15, 2019, nr 2, s. 104-117. 
pochodzi. Z kolei dla pojęcia metod nieodłączny jej rezerwuar odnajdujemy w analizie, syntezie, czy heurezie, które na bazie źródła pozwalają wydobyć z niego informacje, za pomocą postawionych do niego pytań badawczych. Możliwość powszechnego dotarcia do materiałów źródłowych stwarza historykom warunki do optymalnego wykorzystania warsztatu historycznego w pracy badacza, uprawianej na wysokim poziomie naukowości. Należy więc dążyć do usprawnień procedur udostępnienia ich $\mathrm{w}$ ramach obowiązującego prawa, z poszanowaniem własności, czy dbałości o stan zachowania reliktów. Każda ingerencja w ich strukturę, powodująca falsyfikację źródła z wyjątkiem animizacji, godzi w obowiązujące normy etyczne, dlatego szeroka możliwość edycji powinna zostać zapewniona w formie kopii dla ułatwienia czynności opracowywania lub utrwalania wzoru jej reprodukcji ${ }^{5}$. Niezbywalna afirmacja godności ludzkiej stanowi istotny wyznacznik miary, jaką każdy badacz dziejów powinien przykładać do wyciągania wniosków z historii napisanej losami tych pokoleń, których dorobek odziedziczyliśmy, dlatego też wszelkie oceny z perspektywy obecnej pozbawione są jakiejkolwiek wartości naukowej, a jedynie stawiają w krzywym zwierciadle te aktywa przejęte w spadku po naszych przodkach. Konieczne jest danie odporu nieuprawnionej frazeologii, która przejawia brak respektu wobec uwarunkowań i elementarnej wiedzy o danej epoce. Kanon badań historycznych w swoim założeniu przyjmuje, iż punkt wyjścia w naukowej analizie przeszłości stanowi organiczny wysiłek całego środowiska na forum, które poddane zostaje pod rozwagę, czy proces ten uwzględnia kontekst w dochodzeniu do prawdy. Dzieje się tak zwłaszcza w atmosferze atencji odrębnych wobec siebie stanowisk badaczy historycznych zarówno przy okazji debat, jak i odwoływania się do wyników innych i szacowanie ich skali'.

Na proces kształtowania poglądów składają się dwa czynniki. Po pierwsze, dotarcie do źródeł historycznych, a po drugie - warsztat badacza, który pozwala mu na obiektywne wydanie sądów na temat określonego zagadnienia. Nieodłącznieistotnym elementem tego typu działań jest ustalenie poziomu referencyjności w doborze ich pod kątem badań naukowych, by wyniki, jakie uzyskamy, stały się transparentne. Zgodnie z zasadą inferencyjności zakładamy natomiast, że na postawione źródłu pytanie badawcze, znajdujemy w nim samym odpowiedź, bez względu na to, jakiego rodzaju pytanie sformułujemy, co będzie wymagać od badacza odwołania się do wykładni hermeneutyki, a tym samym wychodzenia poza sferę informacji źródłowych, celem zestawienia ich z innymi w obrębie badanego okresu. Kolejna istotna przesłanka dla zasad obiektywizacji wyników wymaga odpowiednich kompetencji, a zatem kluczowych aspektów dla podnie-

Należę do polskiej szkoty historycznej, w: Studia i szkice ofiarowane prof. Jakubowi Goldbergowi z okazji odnowienia doktoratu na Uniwersytecie Łódzkim, red. R. Stobiecki, J. Walicki, Łódź 2010, s. 23-34.

6 K. Zamorski, Kodeks etyki Polskiego Towarzystwa Historycznego, Warszawa 2020. 
sienia autorytatywności. Niemniej należy pamiętać, iż każda tak sprofilowana idea pociąga za sobą różne interpretacje, które nigdy do końca nie powinny być brane za pewnik, bo też nigdy omawiany proces nie jest w pełni skończony i stale podlega weryfikacji naukowej ${ }^{7}$.

W debacie historycznej nie zachodzą okoliczności do atakowania ludzi, lecz jedynie ich poglądów wobec podważenia teorii, na której się zasadzają. Uprawnia się do tego, o ile kwestie percepcji alternatywnego punktu widzenia na zjawisko będą także wzięte pod rozwagę. Opinia w zakresie recenzowania czyjegoś dorobku naukowego musi mieć podstawy merytoryczne, jak i odżegnywać się od subiektywnego czynnika, tzw. konfliktu interesów. Ryzyko stale związane z obostrzeniami praw autorskich, jakie nakłada się na recenzenta, zanim posłuży się zarówno treściami innego autora, jak i swoimi, zachodzi przy realizacji opisu dzieła. Można poddawać weryfikacji badania przeprowadzone z wykorzystaniem pomocy, takich jak edycje źródłowe, których autorstwo edytora jest kwestią względną, a już na pewno niedopuszczalnym zabiegiem jest przypisywanie cudzych efektów realizacji projektu badawczego. Taka reguła może jednak być ograniczona w sytuacji, gdy czyjś dorobek opublikowano w wydaniu popularyzującym stan badań w danej tematyce. Wolność to czynnik nieodzowny w realiach badań i nie może podlegać interpretacjom prawniczym, czy urzędowym, gdyż rozstrzyganie w zakresie samej koncepcji naukowej nie leży w ich gestii. Zaprzeczeniem uprawiania nauk historycznych jest stosowanie z pobudek ideologicznych projekcji światopoglądowej, przy czym stanowczo zabrania się na poziomie narracji historycznej, fałszowania obrazu dziejów i sprowadzania do podrzędnej roli, zależnej od uznania ingerujących w naukę instytucji politycznych, skutkującej jej rozkładem ${ }^{8}$.

Przekaz treści historycznych do obiegu medialnego powinien odbywać się z naciskiem na ich naukowość, nie zaś ulegać szkodliwym wpływom komercjalizmu, który spłyca cel idei badawczych i zaniża tym samym walory historyczne prezentowanego obrazu przeszłości. Taka kreacja w ujęciu epokowych wydarzeń historycznych z udziałem koncernów medialnych winna odbywać się ze szczególnym uwzględnieniem norm, na czele z zasadami poszanowania dla niezależności instytucji nauki, a zwłaszcza determinizmu dziejowego w przeobrażeniu świata. Opatrzenie badań przez najnowszą literaturę i własną pomysłowość daje to, czego nie można osiągnąc jedynie przy pomocy wiedzy, każda nowa osoba wnosi coś szczególnego, własny kod personalny. Wypośrodkowanie języka w istotny sposób pozwala uniknąć poddania pod jedyne wzorce interpretacyjne wyników badań naukowych, które powinny być otwarte z dostępem dla każdego, kto potrafi właściwie je odczytać i zinterpretować. Poprawa nauczania pociąga

M. Kula, Odpowiedzialny historyk? Łatwo powiedzieć..., „Etyka”, 2001, nr 34, s. 87-91.

8 R. Stobiecki, Historyk wobec etyki. Szkic niezobowiazujacy, „Rocznik Antropologii Historii”, R. 3, 2013, nr 1, s. 307-320. 
także za sobą realia w materii dyskusji, języka, metodologii, pojęć, klasyfikacji zjawisk i ich oceny ${ }^{9}$.

Nauczanie historii, jako podstawowa forma jej popularyzacji oparta na faktografii, przy jednoczesnym podkreślaniu szacunku dla prawdy, powinno stymulować postawy dociekliwości i zdolności do takiego ukazywania obrazu dziejowego, w którym jasno określone są granice dla poznania prawdy historycznej. Wiedza bazująca na faktografii dziejowej ma na celu skłonić jej odbiorcę do świadomej postawy orientacji w odwzorowaniu jej przebiegu we współczesności, zarysowując horyzont dla realnych scenariuszy w czasie przyszłym. Podkreślenia wymaga też wyrobienie postaw społecznego statusu samego zawodu historyka, czy też nauczyciela historii. Roztaczany nad nimi, szczególnie w początkowym okresie ich działalności nadzór powinien być roztoczony z uwzględnieniem zasad etycznych na płaszczyźnie uprawiania tej dziedziny ${ }^{10}$.

Obowiązek realizowania zadań z zakresu propagowania i rozpowszechniania wiedzy na tematy historyczne spoczywa na placówkach naukowych, zarówno tych dydaktycznych, jak też i merytorycznych, odpowiedzialnych za gromadzenie spuścizny dziejowej oraz jej sukcesywne opracowywanie. Odnosi się to nie tylko do zespołów badawczych $\mathrm{i}$ ich kierowników, którzy to podejmują działania badawcze, ale również do instytucji publicznych, zarówno państwowych, jak również non profit, które swoim zasięgiem oddziaływania społecznego miałyby znaczący wpływ na wdrażanie w swoich przedsięwzięciach stosownej praktyki prowadzenia naukowego projektu badań, w oparciu o pryncypialne prawa, jakimi rządzą się nauki historyczne. Przekłada się to w stosunkowo dużym stopniu na ich transparentność, gdy przyjęte zostaną z klarownymi zasadami dla trybu procedur związanych z gromadzeniem źródeł, fumigacją, konserwacją, jakie należałoby skrupulatnie przestrzegać w celu przystępniejszej percepcji naukowej, czerpiącej od postaci źródła bezpośrednio dane, mające wpływ na rzetelną ocenę w kontekście osiągniętych rezultatów, które warunkują stale proces ewaluacji, w szczególności dla młodego naukowca ${ }^{11}$.

Niebagatelne znaczenie, warunkujące formowanie kadry młodych badaczy, ma poziom wykształconych narzędzi dla dotowania zwłaszcza procesu wydawniczego, będącego głównym czynnikiem umożliwiającym autorowi opublikowanie własnych wyników, przyczyniając się do większej cytowalności w przypisach. Wyposażanie aparatu naukowego środkami stanowiącymi zaplecze dla jego zadań publikacyjnych, ograniczałoby w stopniu znacznym to ryzyko nadużyć ze sfery powoływania się na formułowane i zgodnie z faktografią historyczną udokumentowane interpretacje, czy ściśle sprecyzowane tezy naukowe na bazie dowodów,

M. Krajewski, O metodologii nauk i zasadach pisarstwa naukowego, Gliwice 2010.

10 S. Kieniewicz, O etyce zawodu historyka, „Kwartalnik Historyczny”, R. 81, 1974, z. 3, s. 517-527.

11 W. Wrzesiński, Etos polskiego historyka, „Komunikaty Mazursko-Warmińskie”, 2001, nr 2, s. $147-156$. 
wpisanych do założeń badawczych, jak również znajdujących się poza obrębem przedmiotu ich badań. Zebrane w ten sposób wnioski w pełni ukazują spektrum badanego zagadnienia i skalę złożoności jego analizy pod kątem wartości intelektualnej, więc historyk ponosi pełnię konsekwencji za formę treści.

Godna nagany praktyka dla historyka to publikacja w postaci naukowej efektów ad hoc hiperbolizujących osiągnięcia, jakie pociąga za sobą analiza zjawiska, pokazując ambiwalentne rzeczywistości badanej problematyki. Za nieetyczne w tym kontekście należy uznać także takie formy upublicznienia nowej wiedzy, zanim zyskają aprobatę środowiska naukowego, czy ujrzą światło dzienne, przypuszczalnie na łamach periodyku lub w wydaniu monografii. Stosuje się te kanony również dla decepcji badawczej oraz autorstwa nie swoich dokonań, zarówno na płaszczyźnie wyzbycia się własności intelektualnej, jak i roszczenia sobie do niej bezzasadnych praw. W pierwszej kolejności obowiązuje w tego typu przypadkach reprymenda publiczna, zaś przy powtórnym popełnieniu wyżej przewidzianych zachowań, dyskwalifikujących naukowca z kręgu środowiskowego, pociągnięty zostaje do odpowiedzialności dyscyplinarnej i karnej.

Ustalenie poziomu etycznego i metafizyczność jest priorytetem, przy zawarciu pewnych ideałów związanych z realizacją danych założeń i bezpieczeństwa nauki dla niej samej i dla jej potencjalnych konsumentów. Stawiając pytanie, czym w istocie są reguły, zasady i kto je ustala, dochodzimy do pojęcia jednorodności, gdyż muszą być uniwersalnym probierzem moralności, jako wyznaczniki norm powszechnie realizowanych w społeczeństwie. Spory wynikające ze sprzecznych stanowisk moralnych i etyka pozostają w gestii jednostki lub środowiska. Zasady, które w jakiejś grupie lub w poczuciu własnej świadomości wyznajemy lub ustalamy, odwołują się do jednostki bądź środowiska, jako idee działania, którymi ludzie chcą się kierować. Można też powiedzieć, że jest to refleksja nad świadomością zbiorowości lub ludzi. Z jednej strony jest to, co uważamy, że nie powinno się robić, a drugi typ zasad to jest to, co powinno się robić, jaki wzór idei należy przyjmować, więc jedne etyczne wartości ustalają nam zasady, a drugie określają nam zakazy. Etyka nauki i etyka w badaniach naukowych dotyczy tych procesów powiązanych z metodologią badań, zaś procesy i efekty oraz forma ich opisania w rozprawie naukowej jest tutaj kluczowa. Empiria określa zakres wartości tez z respektowanej etyki badań. Chodzi o adekwatność wniosku z przeprowadzonymi badaniami i metodą, jaką stosowaliśmy.

Zagadnienia dydaktyczne odnoszą się do sposobu prowadzenia dyskusji dotyczących zarówno spraw naukowych, jak i spraw moralnych, czy życiowych. Prowadzi się je w porządku metodologicznym. Taka dysputa łączy ze sobą zwaśnione strony i doprowadza do wzajemnego dotarcia obu stanowisk. Bazę do tego stwarza traktowanie partnerów naukowych na zasadzie: „nie ten ma rację, kto głośno krzyczy, lecz ten, kto dostarcza więcej przekonujących nas dowodów”. To z kolei również pozwala nam uniknąć wszelkich elementów niekompetencji 
i ignorancji do przedkładania własnych argumentów naukowych, oderwanych od przedkładanych racji. Oparta na neuronaukach dyscyplina myślenia, związana jest ze sposobem rozpatrywania poszczególnych przypadków, będących przedmiotem dylematów oraz budzących wątpliwości natury moralnej, np. oceny wartościujące postawy z przeszłości w kategoriach współczesnych, bądź asumpt dla wykorzystania subiektywnych relacji o przeszłości, istotnej w poprowadzeniu rzeczowej oceny, czy to zasługuje na akceptację, czy zależy nam bardziej na doborze z selekcji wiedzy o epoce ${ }^{12}$.

Tradycyjne pojęcia interpretują zagadnienia przy pomocy aksjomatów, które zawierają model rzeczywistości nieskomponowanych z naszą współczesną wiedzą o świecie. Dylemat co do konstrukcji narracji historycznej, jaki wydaje się palący, stanowi nadawanie różnej definicji pojęciom nowym, jak i starym. Etyka badań dotyczy w tym kontekście poprawnego myślenia. Przygotowanie naukowców do badań oraz do ich inicjacji, doboru pojęć i klasyfikacji poprzez weryfikację w dydaktyce uczelnianej, pozwala określić zadania, jakie stoją przed etyką badań. Krytyka źródłowa wymaga olbrzymiej erudycji, trzeba coś znać i umieć to wielopłaszczyznowo interpretować: albo poddajemy krytyce daną koncepcję i odtwarzamy ją, odczytując w zupełnie innym sensie. Krytyka dąży do pozytywnego rozwiązania łączącego punkty widzenia krytyka z krytykowanym. Uprawianie nauki w określonej dziedzinie i związane z tym doświadczenia mogą stać się również źródłem oddziaływania społecznego i przekazu historycznego po to, by nie uprawiać nauki dla niej samej, ale żeby widzieć jej społeczne zastosowanie w innowacji.

Promocja odwagi w badaniach naukowych odnosi się do dydaktyki i narracji typu case studies - debaty na argumenty, czerpiąc wzorce pozapodręcznikowe, z tzw. nieschematycznej pomysłowości. Kolejny argument odnosi się do zmiany mentalności i krytyki powtarzania tego, co było, a opierało się na innych wzorcach z dziedziny historycznej. Prowadzą ją najwybitniejsi historycy i badacze kultury. Odwaga w tym kontekście stale musi iść w parze z pomysłowością i wyobraźnią, która pozwala nam przekraczać progi tego, co było, a pokazywać efekty tego, że są też inne, nowatorskie możliwości. Wyjście poza utarte schematy, to jest pokazanie, że dotąd obowiązywały założenia stare, ale w tym momencie zmienia się optyka, która pozwala odejść od autorytetów i zastanowić się, jaki inny model założeń przyjąć, dając propozycję nowej wizji. Marketing nauki oznacza nie tyle publikacje, co konferencje i spotkania z wymianą myśli ${ }^{13}$.

Znalezienie takich zasad, które można byłoby stosować we wszystkich dziedzinach, czy też uniwersalnie, określające kategorie zdrowego rozsądku, to ważne założenie modułu działań badawczych. Kategoria racjonalności w nauce podlega

12 A. Górski, Kodeks etyki pracownika naukowego, „Nauka”, t. 3, 2012, s. 33-46.

13 E. McMullin, Wartości w nauce, „Zagadnienia Filozoficzne w Nauce”, t. 24, 1999, s. 7-25. 
uszczegółowieniu, gdyż inaczej będzie nazwana w naukach ścisłych, odmiennie zaś w historycznych. Racjonalność musi być uznana za sprecyzowaną wobec dziedziny, w której zasady jej będą stanowiły pryncypia, jeśli chodzi o badania naukowe. W ich toku należy poszukiwać prawdy i ma to stanowić idiom obejmujący sens badań naukowych w ogóle. Postuluje się, aby nauka, jako największy kapitał ideowy, była kierowana i kontrolowana oraz upowszechniana. Historia to są ideały związane z wyciąganiem wniosków z przeszłości po to, by uczynić przyszłość lepszą, stale utrwalając ją w polu pamięci emocji i rozumu człowieka. Stworzenie świata technicznego jest dla człowieka istotne o tyle, o ile poszerza jego pole egzystencji, więc bez rysu historycznego będzie posiadał wiedzę ślepą.

\section{Bibliografia}

Aleksiun N. i in., Etyka w badaniach przeszłości. Ankieta, ,Rocznik Antropologii Historii", t. 2, 2012, nr 1.

Bocheński J. M., De Virtute Militari. Zarys etyki wojskowej, Kraków 1993.

Górski A., Kodeks etyki pracownika naukowego, „Nauka”, t. 3, 2012.

Kieniewicz S., O etyce zawodu historyka, „Kwartalnik Historyczny”, R. 81, 1974, z. 3.

Krajewski M., O metodologii nauk i zasadach pisarstwa naukowego, Gliwice 2010.

Kula M., Odpowiedzialny historyk? Łatwo powiedzieć..., „Etyka”, 2001, nr 34.

McMullin E., Wartości w nauce, „Zagadnienia Filozoficzne w Nauce”, t. 24, 1999.

Należę do polskiej szkoty historycznej, w: Studia i szkice ofiarowane prof. Jakubowi Goldbergowi z okazji odnowienia doktoratu na Uniwersytecie Łódzkim, red. R. Stobiecki, J. Walicki, Łódź 2010.

Pełka D., Etyka wojskowa i jej współczesne egzemplifikacje w zawodach ratowniczych, ,Filo-Sofija”, t. 2, 2013, nr 21.

Stobiecki R., Historyk wobec etyki. Szkic niezobowiazujacy, „,Rocznik Antropologii Historii”, R. 3, 2013, nr 1.

Terela I., Wybrane problemy etyczne w historii mówionej. Refleksje historyka, „Przegląd Socjologii Jakościowej”, t. 15, 2019, nr 2.

Wrzesiński W., Etos polskiego historyka, „Komunikaty Mazursko-Warmińskie”, $2001, \mathrm{nr} 2$.

Wyszczelski L., Teorie wojenne i ich twórcy na przestrzeni dziejów. Myśl wojskowa od powstania do końca lat osiemdziesiatych XX wieku, Warszawa 2009.

Zamorski K., Kodeks etyki Polskiego Towarzystwa Historycznego, Warszawa 2020. 